\title{
Responses of Maize Varieties to Salt Stress in Relation to Germination and Seedling Growth
}

\author{
Nuurismaan Hassan ${ }^{1,2}$, Md. Kamrul Hasan ${ }^{1}$, Md. Obaidullah Shaddam ${ }^{1}$, \\ Mohammad Sohidul Islam ${ }^{1}$, Celaleddin Barutçular ${ }^{3}$, Ayman EL Sabagh $^{4^{*}}$ \\ ${ }^{1}$ Department of Agronomy, HajeeMohammadDanesh Science and Technology University, \\ Bangladesh
}

\author{
${ }^{2}$ Department of Agriculture, Benadir University, Somalia \\ ${ }^{3}$ Department of Field Crops, Faculty of Agriculture, Cukurova, Turkey \\ ${ }^{4}$ Department of Agronomy, Faculty of Agriculture,Kafrelsheikh University, Egypt
}

ayman.elsabagh@agr.kfs.edu.eg

Keywords: Salinity, maize, germination, root length, shoot length, dry weight

\begin{abstract}
A pot experiment was carried out at the Laboratory of Department of Agronomy, Hajee Mohamad Danesh Science and Technology University (HSTU), Bangladesh during 2016 to evaluate the response of maize varieties at germination and seedling growth stages under salt stress. The seeds of the BARI (Bangladesh Agricultural Research Institute) developed four maize varieties viz. Barnali, Khoi Vutta, Mohor and BARI Maize 5 were placed in plastic pots (each of $25 \mathrm{~cm}$ length and $12 \mathrm{~cm}$ width) on sand bed irrigated with tap water (control), 100 and $200 \mathrm{mM} \mathrm{NaCl} \mathrm{salt}$ solutions. It was replicated in thrice with completely randomized design (CRD). Salinity stress significantly affected the germination characters and seedling growth parameters of maize varieties. The germination percentages (GP) and germination rate (GR) reduced significantly with increasing salinity, and the variety Khoi Vutta showed the highest GP and GR followed by Barnali and Mohor showed the lowest GP and GR followed by BARI maize 5. Under high salinity level, seedling growths characteristics like shoot and root lengths, fresh and dry weight of shoot and roots reduced remarkably in the variety Mohor indicating salt susceptible while the minimum reduction of the aforementioned traits was observed in the variety Khoi Vutta demonstrating high salt tolerant variety. The studied varieties can be ranked on the basis of salt tolerance as Khoi Vutta $>$ Barnali $>$ BARI Maize $5>$ Mohor from the experiment.
\end{abstract}

\section{Introduction}

Maize (Zea mays L.) occupies one of the important cereal crops all over the world. It serves as food and oil for human, feed for livestock and as raw material for industry [1], [2]. It is widely grown in various soil and climatic conditions due to its contribution among cereals in the world. It can play a glorious role in economy of the country by feeding malnourished people as well as solving food problems. Therefore, maize should get priority considering the protein malnourishment of the people, because it encompasses more digestible protein than the other cereals [3]. Furthermore, due to the rising poultry industry in Bangladesh, the need for maize is increasing very sharply as maize is an important component of poultry feed. In Bangladesh, total land area and production of maize are 395500 ha and $279500 \mathrm{~m}$ tons respectively [4].

The world agriculture faced lots of problems due to soil salinity as its damage the various cellular function of plant. The land is becoming non-productive due to accumulation of salt in fresh soil through tidal flow close proximity to sea level in each year. About 300 million ha of irrigated farmland is estimated to be affected by salinity. Four countries viz. China, India, Pakistan and United States provided more than half of all salt-affected irrigated farmlands in the world [5]. The most severe difficulties for crop production in the dry regions are high concentration of toxic ions especially $\mathrm{NaCl}$ either in soil or in irrigation water [6]. Plant growth and productivity drastically restricted by salinity that is of the major environmental factors [7]. The salt stress could be lead to a 
decrease in the growth and productivity of various crops in the world [8-16]. The disruption of intracellular ionic concentration and osmotic gradients inhibiting a number of vital physiological functions reduced by salinity resulting malfunctioning of plant morpho-physiological characters i.e photosynthesis [17], reduction of protein synthesis and activities of enzyme [18], poor nutritional balance (lowering $\mathrm{N}, \mathrm{P}, \mathrm{K}^{+}, \mathrm{Ca}^{2+}$ unbalanced carbon metabolism) [19], and stunted stem length, stem width, stempith diameter, leaf blade thickness, leaf vascular bundle length and leaf xylem vessels [20], [21].

Reduction of nutrient uptake capacity often accompanied by mineral toxicity leading to nutritional imbalance [22]. Soil reclamation and/or improved irrigation techniques (generally expensive) could be a systematic tactics for the management of problematic soils/salt affected soil in the arid and semi-arid tropics of this universe. The most inexpensive and more sustainable solution for using these problematic soils is the crop improvement through genetically or agronomical management. So, improvement of new methods to introduce salt stress resistance and tolerance varieties is so important. By cultivating the tolerant genotype that may sustain a reasonable yield on salt affected soil [23]. The germination and tolerance mechanism greatly varied in crop to crop at growth and seedling stage [24]. The selection criterion for screening salt tolerant individual and increasing salt tolerance in many species is the vigorous growth at the seedling stage [25]. Among all of the life cycle of plant, the germination and seedling stage is the sensitive to salinity than the adult stage [26]. The greater reduction of early seedling and growth stage was observed in wheat and sorghum with increasing salinity [27]. Therefore, the present experiment was carried to evaluate salt tolerance of four maize varieties at germination and seedling growth under saline stress environment.

\section{Materials and Method}

\section{Location and duration}

A pot trial was took place in the laboratory of Department of Agronomy, Hajee Mohamad Danesh Science and Technology University (HSTU), Bangladesh during the period of 01 November to 15 November, 2016.

\section{Plant materials}

The seeds of the four maize varieties viz. Barnali, Khoi Vutta, Mohor and BARI Maize 5 were used in this experiment. The seeds of those varieties were collected from Bangladesh Agriculture Research Institute (BARI), Gazipur, Bangladesh. The properties of maize varieties are presented in Table 1 [28].

\section{Temperature (maximum, minimum and average) and relative humidity}

The daily weather data (average) on temperature and humidity during experimental period were recorded from the Meteorological Station, HSTU, Dinajpur, Bangladesh. The temperature fluctuated from 12 to $24 \mathrm{oC}$ and the average temperature was around $18 \mathrm{oC}$ during seed germination and seedling growth test. The minimum humidity of those days was $47 \%$ and maximum was $57 \%$. The data on temperature (maximum, minimum and average) and humidity are presented in Fig. 1 
Table 1. Characteristics of existing maize varieties used in the present research.

\begin{tabular}{|c|c|c|c|c|}
\hline Varieties & $\begin{array}{l}\text { Year of } \\
\text { release }\end{array}$ & $\begin{array}{l}\text { Life span } \\
\text { (days) }\end{array}$ & $\begin{array}{l}\text { 1000-grain } \\
\text { weight }(\mathrm{g})\end{array}$ & Major grain properties, diseases and pest \\
\hline Barnali & 1986 & $140-145$ & $245-320$ & $\begin{array}{l}\text { Golden yellow, semi-flint, large cob size, } \\
\text { pointed at the tip, almost resistant to diseases } \\
\text { and pests. }\end{array}$ \\
\hline Khoi Vutta & 1986 & $125-130$ & $140-150$ & $\begin{array}{l}\text { Bright yellow, flint, suited for its high } \\
\text { popping per cent }(>95 \%) \text { and popping } \\
\text { quality, almost resistant to diseases and pests. }\end{array}$ \\
\hline Mohor & 1991 & $135-145$ & $180-300$ & $\begin{array}{l}\text { Bright yellow, flint, large cob girth, open } \\
\text { pollinated, suitable for fodder purpose. }\end{array}$ \\
\hline BARI Maize 5 & 1998 & $145-155$ & $290-310$ & $\begin{array}{l}\text { Bright yellow, flint, open pollinated, } \\
\text { resistance to diseases, pests and lodging. }\end{array}$ \\
\hline
\end{tabular}

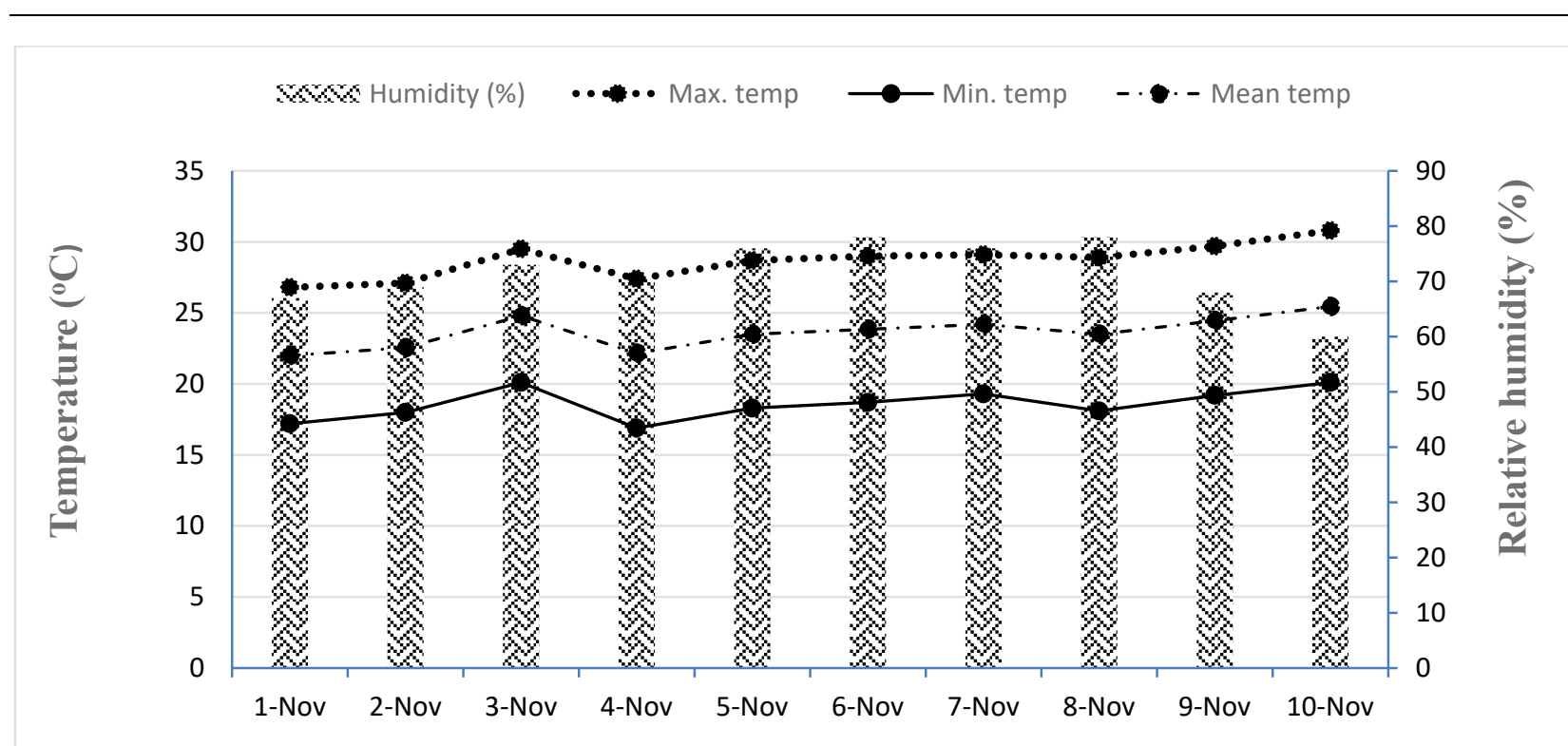

\section{Different dates}

Figure 1. Weather data on temperature (maximum, minimum and average) and relative humidity during experimentation.

\section{Experimental treatments and design}

Three levels of salinity viz. 0,100 and $200 \mathrm{mM} \mathrm{NaCl}$ was used for salt treatments completely randomized design (CRD) with five replications. Before sowing, the seeds were sterilized and thoroughly rinsed with $1 \%$ mercuric chloride solution with distilled water, respectively for 2 minutes. The dissolved calculated amount of $\mathrm{NaCl}$ in tap water was used to make saline solutions of 100 and $200 \mathrm{mM}$. Fresh water collected from tap was used as control.

\section{Experimental procedure}

The seeds of maize varieties were germinated in plastic pots $(25 \mathrm{~cm} \mathrm{x} 12 \mathrm{~cm})$ on sand bed culture. One hundred seeds were sown in equal distances between seeds and between lines in each tray. The treatments were imposed with tap water for control and calculated amount $\mathrm{NaCl}$ salt solutions for creating 100 and $200 \mathrm{mM} \mathrm{NaCl}$ salt stress as necessary for obtaining desire moisture condition. Appropriate care and pest-diseases control were confirmed in each pot during the experimental period. 


\section{Data collection}

Interval at 24-hour and continued up to $10^{\text {th }}$ day $(240 \mathrm{~h})$, germination was counted. The seed considered as germinated seedling, when the plumule and radicle came out about $>2 \mathrm{~mm}$ long from seed.

\section{Germination percentage}

The following formulae were used to calculate the germination percentage.

Germination percentage $=\frac{\text { No. of seeds germinated at final count }}{\text { No. of seeds placed for germination }} \times 100$

\section{Rate of germination}

By using the following formulae [29], the germination rate was calculated.

Rate of germination $(\%)=\frac{\text { No. of seeds germinated at } 72 \mathrm{~h}}{\text { No. of seeds germinated at } 240 \mathrm{~h}} \times 100$

\section{Shoot and root lengths}

Seedlings from each plastic pot were collected as a sampling after placement for germination at 10 days. Scale was used to measure the shoot and root length $(\mathrm{cm})$ of individual seedling.

\section{Fresh and dry weight of shoot and root}

Shoot and root were weighed separately in fresh condition. The mean shoot and root fresh weight were calculated by total weight divided by total number of plants. For measuring the shoot and root dry weight, an electric oven was used at $80^{\circ} \mathrm{C}$ for $72 \mathrm{~h}$ and weights were recorded through an electrical balance.

\section{Statistical analysis}

The collected data were analysed statistically and means were adjudged by DMRT at 1 and $5 \%$ level of probability. The data were analysed with the help of computer using ' $\mathrm{R}$ 'Command program.

\section{Results and Discussion}

\section{Germination percentage}

Salinity caused a considerable delay and reduction in seed germination. The germination percentage (GP) of different maize varieties drastically reduced and the varieties showed dissimilar results with increasing salt stress (Table 2). At $100 \mathrm{mM} \mathrm{NaCl}$ salinity level, the maximum reduction in GP (34.87\%) was found in Mohor followed by the variety BARI Maize $5(33.96 \%)$ and the minimum reduction (13.59\%) was found in Khoi Vutta which is followed by the varieties of Barnali (16.81\%) when compared to control. Again at high salinity level $(200 \mathrm{mM} \mathrm{NaCl})$, the GP reduced severely in all maize varieties. The maximum reduction (57.74\%) was noted in Mohor whereas the minimum reduction $(23.73 \%$ ) was noted in Khoi Vutta when compared to control condition. It is indicated that the GP decreased significantly with the increasing salinity levels. The osmotic potential which retards the uptake of water necessary for mobilization of nutrients disturb by salt stress resulting reduction of germination. The result of confirms the results of [30], [31], in maize. The osmotic effect of salts present in the growth medium gradually decreased the germination percentage as reported by [32]. 


\section{Germination rate}

Salinization resulted in a general reduction of germination rate (GR) for all the varieties and showed varied responses among the varieties to the increased levels of salinity (Table 3). The maximum GR (138.51\%) was documented in the variety of Khoi Vutta while the lowest (108.39\%) was documented in the variety of Mohor which was statistically similar with the variety of BARI Maize 5 (109.42\%) under control condition. Moreover, at $100 \mathrm{mM} \mathrm{NaCl}$ salinity level, the maximum reduction of GR $(32.63 \%)$ was recorded in BARI Maize 5, in contrast the minimum reduction $(15.30 \%)$ was observed from Khoi Vutta. On the other hand, at high salinity level (200 $\mathrm{mM} \mathrm{NaCl}$ ) harshly reduced the germination rates of all maize varieties. The maximum reduction $(59.40 \%)$ was noted in Mohor followed by BARI Maize $5(57.26 \%)$ though the minimum reduction $(41.46 \%)$ was recorded in Khoi Vutta over control condition. The main reason of reducing germination rate are the toxic effects of certain ions and higher concentration of salt disturbs the water potential in the medium which hinders water absorption by germinating seeds [33], [34].

Table 2. Germination percentage of maize varieties as influenced by salt stress.

\begin{tabular}{lccccc}
\hline \multirow{2}{*}{ Genotypes } & \multicolumn{5}{c}{ Germination percentage (\%) } \\
& Control & $100 \mathrm{mM}$ & \% Reduction & $200 \mathrm{mM}$ & \% Reduction \\
\hline Barnali & $94.00 \mathrm{~b}$ & $79.20 \mathrm{e}$ & 16.81 & $61.06 \mathrm{~g}$ & 35.04 \\
Khoi Vutta & $98.33 \mathrm{a}$ & $84.96 \mathrm{~d}$ & 13.59 & $75.00 \mathrm{f}$ & 23.73 \\
Mohor & $87.43 \mathrm{c}$ & $56.94 \mathrm{~h}$ & 34.87 & $36.95 \mathrm{j}$ & 57.74 \\
BARI Maize 5 & $85.39 \mathrm{~d}$ & $56.39 \mathrm{~h}$ & 33.96 & $47.22 \mathrm{i}$ & 44.70 \\
LS & & $* *$ & & $* *$ & \\
CV (\%) & & & & & \\
\hline
\end{tabular}

Values having same letter (s) do not differ significantly by DMRT at $\mathrm{P}<5 \%$ level

** Highly significant $(\mathrm{p} \leq 1 \%)$

$\mathrm{CV}=$ Coefficient variation, $\mathrm{LS}=$ Level of significance

Table 3. Germination rate of maize varieties as influenced by salt stress.

\begin{tabular}{|c|c|c|c|c|c|}
\hline \multirow[b]{2}{*}{ Varieties } & \multicolumn{5}{|c|}{ Germination rate $(\%)$} \\
\hline & Control & $100 \mathrm{mM}$ & $\%$ Reduction & $200 \mathrm{mM}$ & \% Reduction \\
\hline Barnali & $121.12 \mathrm{~b}$ & $99.20 \mathrm{e}$ & 18.10 & $61.09 \mathrm{i}$ & 49.56 \\
\hline Khoi Vutta & $138.51 \mathrm{a}$ & $117.31 \mathrm{c}$ & 15.30 & $81.08 \mathrm{f}$ & 41.46 \\
\hline Mohor & $108.39 \mathrm{~d}$ & $75.18 \mathrm{~g}$ & 30.51 & $44.01 \mathrm{j}$ & 59.40 \\
\hline BARI Maize 5 & $109.42 \mathrm{~d}$ & $73.72 \mathrm{~h}$ & 32.63 & $46.76 \mathrm{j}$ & 57.26 \\
\hline LS & \multicolumn{2}{|c|}{$* *$} & & ** & \\
\hline CV (\%) & & & 1.03 & & \\
\hline
\end{tabular}

Values having same letter (s) do not differ significantly by DMRT at $\mathrm{P}<5 \%$ level

** Highly significant $(\mathrm{p} \leq 1 \%)$

$\mathrm{CV}=$ Coefficient variation, $\mathrm{LS}=$ Level of significance

\section{Root length}

Maize varieties faced a significant reduction in root lengths due to salinity (Table 4). However, the root lengths were significantly lower at $100 \mathrm{mM} \mathrm{NaCl}$ concentration over control but greater than the subsequent higher salt stress for all the varieties. The highest root length $(29.47 \mathrm{~cm})$ was obtained in Khoi Vutta but the lowest $(23.73 \mathrm{~cm})$ was obtained from Barnali which was statistically similar with Mohor $(24.24 \mathrm{~cm})$ and BARI Maize $5(24.45 \mathrm{~cm})$ under control condition. At moderate salt stress $(100 \mathrm{mM} \mathrm{NaCl})$ Barnali showed the highest reduction $(10.78 \%)$ in root length while Khoi vutta displayed the lowest reduction $(7.50 \%)$ which was followed by the BARI Maize 5 (9.08\%). On the other hand, at high salt stress $(200 \mathrm{mM} \mathrm{NaCl})$, Mohor showed the highest reduction (30.82\%) in root length followed by Barnali whereas the lowest reduction (22.05\%) was documented in Khoi Vutta. This reduction may be that the root growth is sensitive to the high salt 
concentration available in the medium. The root length and biomass of all the wheat cultivars tested in their study dramatically reduced with greater amount of imposing $\mathrm{NaCl}$ stress as mentioned by [35],[36].

Table 4. Root length of maize varieties as influenced by salt stress.

\begin{tabular}{lccccc}
\hline \multicolumn{1}{c}{ Varieties } & Control & $\mathbf{1 0 0} \mathbf{~ m M}$ & $\begin{array}{c}\text { Root length }(\mathbf{c m}) \\
\text { \% Reduction }\end{array}$ & $\mathbf{2 0 0 ~} \mathbf{~ m M}$ & \% Reduction \\
\hline Barnali & $23.73 \mathrm{~cd}$ & $21.17 \mathrm{de}$ & 10.78 & $16.53 \mathrm{~g}$ & 30.34 \\
Khoi Vutta & $29.47 \mathrm{a}$ & $27.26 \mathrm{~b}$ & 7.50 & $22.97 \mathrm{~d}$ & 22.05 \\
Mohor & $24.24 \mathrm{c}$ & $21.80 \mathrm{~d}$ & 10.07 & $16.77 \mathrm{f}$ & 30.82 \\
BARI Maize 5 & $24.45 \mathrm{c}$ & $22.23 \mathrm{~d}$ & 9.08 & $17.96 \mathrm{f}$ & 26.54 \\
LS & & $* *$ & & $* *$ & \\
CV (\%) & & & 2.59 & & \\
\hline
\end{tabular}

Values having same letter (s) do not differ significantly by DMRT at $\mathrm{P}<5 \%$ level

** Highly significant $(\mathrm{p} \leq 1 \%)$

$\mathrm{CV}=$ Coefficient variation, $\mathrm{LS}=$ Level of significance

\section{Shoot length}

The highest shoot length $(35.90 \mathrm{~cm})$ was produced by Khoi Vutta but the lowest $(31.60 \mathrm{~cm})$ was observed from BARI Maize 5 under control condition. However, at moderate salt stress (100 $\mathrm{mM} \mathrm{NaCl}$ ) Barnali, Mohor and BARI Maize 5 presented more than 25\% reduction of shoot length whereas Khoi Vutta presented less than 18\%. Furthermore, Barnali, BARI Maize 5, and Mohor exhibited more than $40 \%$ reduction at high salt stress $(200 \mathrm{mM} \mathrm{NaCl})$ although Khoi Vutta exhibited only $20.14 \%$ reduction at the same stress (Table 5). The acceleration of leaf abscission and inter-nodal development as well as shoot growth drastically reduced by salinity stress as confirmed by [37], [38], [39]. This result is consistent with the result of [39].

Table 5. Shoot length of maize varieties as influenced by salt stress.

\begin{tabular}{|c|c|c|c|c|c|}
\hline \multirow[b]{2}{*}{ Varieties } & \multicolumn{5}{|c|}{ Shoot length (cm) } \\
\hline & Control & $100 \mathrm{mM}$ & \% Reduction & $200 \mathrm{mM}$ & \% Reduction \\
\hline Barnali & $33.29 \mathrm{c}$ & $24.11 \mathrm{~h}$ & 27.58 & $19.33 \mathrm{i}$ & 41.93 \\
\hline Khoi Vutta & $35.90 \mathrm{a}$ & $29.65 \mathrm{e}$ & 17.41 & $28.67 \mathrm{f}$ & 20.14 \\
\hline Mohor & $34.07 \mathrm{~b}$ & $24.92 \mathrm{~g}$ & 26.86 & $18.29 \mathrm{j}$ & 46.32 \\
\hline BARI Maize 5 & $31.60 \mathrm{~d}$ & $23.68 \mathrm{~h}$ & 25.06 & $17.89 \mathrm{j}$ & 43.39 \\
\hline LS & \multicolumn{2}{|c|}{$* *$} & \multicolumn{3}{|c|}{$* *$} \\
\hline CV (\%) & & & 1.62 & & \\
\hline
\end{tabular}

Values having same letter (s) do not differ significantly by DMRT at $\mathrm{P}<5 \%$ level

** Highly significant $(\mathrm{p} \leq 1 \%)$

$\mathrm{CV}=$ Coefficient variation, Level of significance

\section{Root fresh weight}

Significant variation of root fresh weight among treatments of all the maize varieties was found when grown under normal and saline conditions. Due to increase in salinity, the shoot fresh weight decreased significantly for all the maize varieties (Table 6). However, at $100 \mathrm{mM}$ saline condition, the maximum reduction $(25.35 \%)$ was documented in Mohor whereas the minimum reduction $(16.87 \%$ ) was in Khoi Vutta. Furthermore, under $200 \mathrm{mM}$ saline condition, the maximum reduction (46.48\%) was recorded in Mohor showing more susceptible variety. Contrarily, the minimum reduction was observed in Khoi Vutta (33.73\%) followed by Barnali $(41.18 \%)$ when compared to the control. Moreover, the effect of salt stress at $200 \mathrm{mM} \mathrm{NaCl}$ concentration on root fresh weight was different among varieties. Similar results were reported by [40], for wheat and [41], for cotton. 
Table 6. Root fresh weight of maize varieties as influenced by salt stress.

\begin{tabular}{lccccc}
\hline \multirow{2}{*}{ Varieties } & \multicolumn{5}{c}{ Root fresh weight (g) } \\
& Control & $\mathbf{1 0 0 ~} \mathbf{~ m M}$ & \% Reduction & $\mathbf{2 0 0 ~} \mathbf{~ m M}$ & \% Reduction \\
\hline Barnali & $0.51 \mathrm{~cd}$ & $0.41 \mathrm{de}$ & 19.61 & $0.30 \mathrm{j}$ & 41.18 \\
Khoi Vutta & $0.83 \mathrm{a}$ & $0.69 \mathrm{~b}$ & 16.87 & $0.55 \mathrm{c}$ & 33.73 \\
Mohor & $0.71 \mathrm{~b}$ & $0.53 \mathrm{~cd}$ & 25.35 & $0.38 \mathrm{~d}$ & 46.48 \\
BARI Maize 5 & $0.71 \mathrm{~b}$ & $0.55 \mathrm{c}$ & 22.54 & $0.40 \mathrm{e}$ & 43.66 \\
LS & & $* *$ & & $* *$ & \\
CV (\%) & & & 3.01 & & \\
\hline
\end{tabular}

Values having same letter (s) do not differ significantly by DMRT at $\mathrm{P}<5 \%$ level

** Highly significant $(\mathrm{p} \leq 1 \%)$

$\mathrm{CV}=$ Coefficient variation, $\mathrm{LS}=$ Level of significance

\section{Shoot fresh weight}

Shoot fresh weight of maize varieties was significantly inhibited by the salinity but the trend of inhibition at 100 and $200 \mathrm{mM}$ saline treatments was not similar for all varieties (Table 7). However, the maximum reduction in shoot fresh weight was exposed in BARI Maize $5(18.28 \%)$ followed by the variety Mohor (17.44\%) and the minimum reduction $(7.29 \%)$ was received in Khoi Vutta at $100 \mathrm{mM} \mathrm{NaCl}$ but at the highest salinity level of $200 \mathrm{mM} \mathrm{NaCl}$, the maximum reduction of shoot fresh weight $(41.86 \%)$ was observed from the variety Mohor although the minimum reduction $(25.00 \%)$ was documented in Khoi Vutta. The result showed that the increase in salinity level, fresh root weight reduced significantly. Salt stress showed a significant reduction in fresh and dry weights of shoot of two maize cultivars with the increase of stress treatments [33].

Table 7. Shoot fresh weight of maize varieties as influenced by salt stress.

\begin{tabular}{|c|c|c|c|c|c|}
\hline \multirow{2}{*}{ Varieties } & \multicolumn{5}{|c|}{ Shoot fresh weight (g) } \\
\hline & Control & $100 \mathrm{mM}$ & \% Reduction & $200 \mathrm{mM}$ & \% Reduction \\
\hline Barnali & $0.93 \mathrm{ab}$ & $0.81 \mathrm{de}$ & 12.90 & $0.65 \mathrm{~g}$ & 30.11 \\
\hline Khoi Vutta & $0.96 \mathrm{a}$ & $0.89 \mathrm{bc}$ & 7.29 & $0.72 \mathrm{f}$ & 25.00 \\
\hline Mohor & $0.86 \mathrm{~cd}$ & $0.71 \mathrm{f}$ & 17.44 & $0.50 \mathrm{hi}$ & 41.86 \\
\hline BARI Maize 5 & $0.93 \mathrm{ab}$ & $0.76 \mathrm{ef}$ & 18.28 & $0.56 \mathrm{~h}$ & 39.78 \\
\hline Level of significance & \multicolumn{2}{|c|}{$* *$} & \multicolumn{3}{|c|}{$* *$} \\
\hline CV (\%) & \multicolumn{5}{|c|}{2.57} \\
\hline
\end{tabular}

Values having same letter (s) do not differ significantly by DMRT at $\mathrm{P}<5 \%$ level

** Highly significant $(\mathrm{p} \leq 1 \%)$

$\mathrm{CV}=$ Coefficient variation

\section{Root dry weight}

It was evident that there was significant variation of root dry weight among the treatments in all maize varieties (Table 8$)$. The heaviest root dry weight $(0.67 \mathrm{~g})$ was obtained in Khoi Vutta although the slightest $(0.34 \mathrm{~g})$ was obtained in Barnali under control condition. At moderate stress $(100 \mathrm{mM} \mathrm{NaCl})$ Barnali, Mohor and BARI Maize 5 showed more than 20\% reduction whereas Khoi Vutta showed less $12 \%$ reduction of root dry weight. At high stress (200 mM NaCl) Barnali, Mohor and BARI Maize 5 reduced more than $40 \%$ of root dry weight but Khoi Vutta reduced less than $33 \%$ of root dry weight over the control. Salt stress increased the metabolic energy cost and reduced carbon gain resulting decreased in root dry weight. The photosynthetic rates of leaf area greatly hampered by salt stress resulting reduction of dry weight [42]. This result is accordance with the result of [33], in maize cultivars 
Table 8. Root dry weight of maize varieties as influenced by salt stress.

\begin{tabular}{|c|c|c|c|c|c|}
\hline \multirow{2}{*}{ Varieties } & \multicolumn{5}{|c|}{ Root dry weight (g) } \\
\hline & Control & $100 \mathrm{mM}$ & $\%$ Reduction & $200 \mathrm{mM}$ & \% Reduction \\
\hline Barnali & $0.34 \mathrm{de}$ & $0.27 \mathrm{fg}$ & 20.59 & $0.20 \mathrm{~h}$ & 41.17 \\
\hline Khoi Vutta & $0.67 \mathrm{a}$ & $0.59 \mathrm{~b}$ & 11.94 & $0.45 \mathrm{c}$ & 32.84 \\
\hline Mohor & $0.54 \mathrm{~b}$ & $0.41 \mathrm{c}$ & 24.07 & $0.30 \mathrm{ef}$ & 44.44 \\
\hline BARI Maize 5 & $0.40 \mathrm{~cd}$ & 0.31 ef & 22.50 & $0.23 \mathrm{gh}$ & 42.50 \\
\hline LS & \multirow{2}{*}{\multicolumn{2}{|c|}{$* *$}} & & $* *$ & \\
\hline $\mathrm{CV}(\%)$ & & & \multicolumn{3}{|l|}{2.01} \\
\hline
\end{tabular}

Values having same letter (s) do not differ significantly by DMRT at $\mathrm{P}<5 \%$ level

** Highly significant $(\mathrm{p} \leq 1 \%)$

$\mathrm{CV}=$ Coefficient variation, $\mathrm{LS}=$ Level of Significant

\section{Shoot dry weight}

Shoot dry weight of maize varieties was affected significantly by salinity (Table 9). At control condition there was non-significant variation among maize varieties. The results indicated that maximum reduction of shoot dry weight $(22.08 \%)$ was detected in Mohor followed by BARI Maize 5 even though the minimum reduction (12.35\%) was revealed in Khoi Vutta at $100 \mathrm{mM} \mathrm{NaCl}$ concentration compared to the control. On the other hand, Khoi Vutta successfully tolerated 200 $\mathrm{mM} \mathrm{NaCl}$ salinity and exhibited only $20.99 \%$ reduction in shoot dry weight while Mohor evidenced to be sensitive and shoot dry weight severely reduced up to $43.75 \%$. The combination of osmotic and specific ion effects of $\mathrm{Cl}^{-}$and $\mathrm{Na}^{+}$result of salinity that are the reason of reducing the shoot dry weight [43], [44], [17]. The value of shoot dry weights of maize cultivars were negatively affected by increasing salt concentration [45].

Table 9. Shoot dry weight of maize varieties as influenced by salt stress.

\begin{tabular}{|c|c|c|c|c|c|}
\hline \multirow{2}{*}{ Varieties } & \multicolumn{5}{|c|}{ Shoot dry weight (g) } \\
\hline & Control & $100 \mathrm{mM}$ & $\%$ Reduction & $200 \mathrm{mM}$ & \% Reduction \\
\hline Barnali & $0.78 \mathrm{a}$ & $0.63 \mathrm{c}$ & 19.23 & $0.48 \mathrm{~d}$ & 38.46 \\
\hline Khoi Vutta & $0.81 \mathrm{a}$ & $0.71 \mathrm{~b}$ & 12.35 & $0.64 \mathrm{c}$ & 20.99 \\
\hline Mohor & $0.77 \mathrm{a}$ & $0.60 \mathrm{c}$ & 22.08 & $0.45 \mathrm{~d}$ & 43.75 \\
\hline BARI Maize 5 & $0.79 \mathrm{a}$ & $0.62 \mathrm{c}$ & 21.52 & $0.51 \mathrm{~d}$ & 35.44 \\
\hline LS & \multirow{2}{*}{\multicolumn{2}{|c|}{$* *$}} & & $* *$ & \\
\hline CV (\%) & & & \multicolumn{3}{|l|}{4.97} \\
\hline
\end{tabular}

Values having same letter (s) do not differ significantly by DMRT at $\mathrm{P}<5 \%$ level

Values in parenthesis indicate reduction percent values to the control

** Highly significant $(\mathrm{p} \leq 1 \%)$

$\mathrm{CV}=$ Coefficient variation, $\mathrm{LS}=$ Level of significance

\section{Conclusion}

From the above results it can be concluded, the screening of maize varieties under salt stress showed that germination and seedling growth parameters of maize varieties were affected by salinity but the effect was dissimilar among the varieties. The variety of Khoi Vutta showed less reduction of germination and seedling growth traits due to salt stress as compared to control condition indicating resistance to salt stress while Mohor exhibited the maximum reduction of those traits under salt condition which signifying susceptibility to salt stress. So Khoi Vutta may be recommended to grow in saline areas of the Southern part of Bangladesh. 


\section{Acknowledgements}

This research was undertaken as part of a national research program of the University Grants Commission (UGC), through Institute of Research and Technology (IRT), Hajee Mohammad Danesh Science and Technology (HSTU), Dinajpur, Bangladesh with the financial support (No. 4829) of HSTU from the annual research budget.

We are very grateful to the Chairman and all the personnel of the Department of Agronomy, HSTU, Dinajpur for their help during experimentation. We are also thankful to honourable vicechancellor, HSTU and Director, IRT to provide fund and uninterrupted support during the research trial.

\section{Conflict of interest}

The authors declare no conflicts of interest.

\section{References}

[1] T. Khatoon et al., Morphological variations in maize (Zea mays L.) under different levels of $\mathrm{NaCl}$ at germinating stage, World Applied Science of Journal. 8(10) (2010) 1294-1297.

[2] I. Ullah, M. Ali, A. Farooqi, Chemical and nutritional properties of some maize (Zea mays L.) varieties grown in NWFP, Pakistan, Pakistan of Journal of Nutrition. 9(11) (2010) 1113-1117.

[3] K.U. Ahamed, Efficacy of indigenous mulches on maize-pulse association, Ph.D. Thesis, Department of Crop Botany, Bangladesh Agricultural University, Mymensingh, 2010.

[4] AIS (Agricultural Information Service) Krishi Diary 2017 (Agricultural Diary 2017), Agricultural Information Service, Khamarbari, Farmgate, Dhaka-1215, Bangladesh, 2017.

[5] FAO ITPS, Status of the World's Soil Resources (SWSR). Main Report, Food and Agriculture Organization of the United Nations and Intergovernmental Technical Panel on Soils, Rome, Italy, 2015.

[6] H. Moeinrad, The relationship between some physiological traits and salt tolerance in pistachio genotypes, Desert. 13(2) (2008) 129-136.

[7] U. Schleiff, Analysis of water supply of plants under saline soil conditions and conclusions for research on crop salt tolerance, Journal of Agronomy and Crop Science. 194 (2008) 1-8.

[8] M.S. Islam et al., Comparative studies on growth and physiological responses to saline and alkaline stresses of Foxtail millet (Setaria italica L.) and Proso millet (Panicum miliaceum L.), Australian Journal of Crop Science. 5(10) (2011) 1269-1277.

[9] A. EL Sabagh et al., Increasing reproductive stage tolerance to salinity stress in soybean, Int. J. Agric. Crop Sci. 8(5) (2015) 738-745.

[10] A. EL Sabagh et al., Comparative physiological study of soybean (Glycine max L.) cultivars under salt stress, Yyu. J. Agr. Sci. 25(3) (2015) 269-278.

[11] A. EL Sabagh et al., Physiological performance of soybean germination and seedling growth under salinity stress, Dicle University Inst. Nat. Apd. Sci. J. 4(1) (2015) 6-15.

[12] A. EL Sabagh et al., Alleviation of adverse effects of salt stress on soybean (Glycine max L.) by using osmoprotectants and compost application, Int. J. Biol. Biomol. Agril. Food Biotech. Eng. 9(9) (2015).

[13] A. EL Sabagh et al., Evaluation of salinity stress effects on seed yield and quality of three soybean cultivars, Azarian Journal of Agriculture. 2(5) (2015) 138-141.

[14] M.H. Abd El-Wahed et al., Evaluation of barley productivity and water use efficiency under saline water irrigation in arid region, Int. J. Agr. Crop. Sci. 8 (2015) 765-773. 
[15] Md.K. Hasan et al., Comparative adaptable agronomic traits of blackgram and mungbean for saline lands, Plant Archives. 17(1) (2017) 589-593.

[16] M. Rahman et al., Evaluation of salt tolerance mungbean genotypes and mitigation of salt stress through potassium nitrate fertılizatıon, Fresenius Environmental Bulletin. 26(12) (2017) 7218-7226.

[17] M.S. Islam, Nutrio-physiological studies on saline and alkaline toxicities and tolerance in Foxtail millet (Setaria italica L.) and Proso millet (Panicum miliaceum L.), Ph.D. Thesis, Department of Environmental Dynamics and Management, Hiroshima University, HigashiHiroshima, Japan, 2012.

[18] M.S. Sadak, M.T. Abdelhamid, Influence of amino acids mixture application on some biochemical aspects, antioxidant enzymes and endogenous polyamines of Vicia faba plant grown under seawater salinity stress, Gesunde Pflanzen. 67(3) (2015) 119-129.

[19] M.T. Abdelhamid et al., Exogenous application of proline alleviates salt-induced oxidative stress in Phaseolus vulgaris plants, Journal of Horticultural Science and Biotechnology. 88 (2013) 439-446.

[20] M.G. Dawood et al., The changes induced in the physiological, biochemical and anatomical characteristics of Vicia faba by the exogenous application of proline under seawater stress, South African Journal of Botany. 93 (2014) 54-63.

[21] W.M. Semida, M.M. Rady, Presoaking application of propolis and maize grain extracts alleviatessalinity stress in common bean (Phaseolus vulgaris L.), Scientia Horticulturae. 168 (2014) 210-217.

[22] Y. Hu, U. Schmidhalter, Drought and salinity: a comparison of their effects on mineral nutrition of plants, Journal of Plant Nutrition and Soil Science. 168(4) (2005) 541-549.

[23] M.Y. Ashraf et al., Evaluation of arid and semi-arid ecotypes of guar (Cyamopsis tetragonoloba L.) for salinity ( $\mathrm{NaCl})$ tolerance, Journal of Arid Environment. 52 (2006) 473482.

[24] J. Shalhevet, Root and shoot growth responses to salinity in maize and soybean, Agronomy Journal. 87(3) (1995) 512-516.

[25] T. McKimmie, A.K. Dobrenz, Ionic concentrations and water relations of alfalfa seedlings differing in salt tolerance, Agronomy Journal. 83(2) (1991) 363-367.

[26] M. Ashraf, T. McNeilly, A.D. Bradshaw, The response to $\mathrm{NaCl}$ and ionic contents of selecte salt tolerant and normal lines of three legume forage species in sand culture, New Phytology. 104(3) (1986) 403-471.

[27] J. Shalhevet, Using water of marginal quality for crop production: Major issues, Agricultural Water Management. 25(3) (1994) 233-269.

[28] BARI (Bangladesh Agricultural Research Institute), A Hand of Agricultural Technology (Krishi Projuktir Hat Boi). Bangladesh Agricultural Research Institute, Joydebpur, Gazipur, Bangladesh, 2012.

[29] K. Maghsoudi, M.J. Arvin, Salicylic acid and osmotic stress effects on seed germination and seedling growth of wheat (Triticum aestivum L.) cultivars, Plant Ecophysiology. 2 (2010) 7 11.

[30] A. Farsiani, M.E. Ghobadi, Effect of PEG and NaCl stress on two cultivars of Corn (Zea mays L.) at germination and early seedling stages, International Journal of Agricultural and Biosystems Engineering. 3(9) (2009) 442-445. 
[31] M. Khayatnezhad et al., Effects of peg stress on corn cultivars (Zea mays L.) at germination stage, World Applied Science Journal. 11(5) (2010) 504-506.

[32] M. Rejili et al., Influence of temperature and salinity on the germination of Lotus creticus (L.) from the arid land of Tunisia, African Journal of Ecology. 48(2) (2010) 329-337.

[33] N. Cicek, H. Cakirlar, The effect of salinity on some physiological parameters in two maize cultivars, Bulgarian Journal of Plant Physiology. 28(1-2) (2002) 66-74.

[34] M. Jamil et al., Effect of salt $(\mathrm{NaCl})$ stress on germination and early seedling growth of four vegetables species, Journal of Central European Agriculture. 7(2) (2006) 273-282.

[35] R. Mujeeb et al., Effects of $\mathrm{NaCl}$ salinity on wheat (Triticum aestivum L.) cultivars, World Journal of Agricultural Sciences. 4(3) (2008) 398-403.

[36] M. Khatun et al., Responses of wheat genotypes to salt stress in relation to germination and seedling growth, International Journal of Bio-resource and Stress Management. 4(4) (2013) 635-640.

[37] K. Rios-Gonzalez, L. Erdei, S.H. Lips, The activity of antioxidant enzymes in maize and sunflower seedlings as affected by salinity and different nitrogen sources, Plant Science 162(6) (2002) 923-930.

[38] M. Akram et al., Allometry and yield components of maize (Zea mays L.) hybrids to various potassium levels under saline conditions, Architecture Biology Science Belgrade. 62 (2010) 1053-1061.

[39] C. Qu et al., Impairment of maize seedling photosynthesis caused by a combination of potassium deficiency and salt stress, Environmental and Experimental Botany. 75 (2012) 134141.

[40] G. Sarwar, M.Y. Ashraf, Genetic variability of some primitive bread wheat varieties to salt tolerance, Pakistan Journal Botany. 35 (2003) 771-777.

[41] D.A. Meloni et al., Contribution of proline and inorganic solutes to osmotic adjustment in cotton under salt stress, Journal of Plant Nutrition. 24 (2001) 599-612.

[42] G.W. Netondo, J.C. Onyango, E. Beck, Sorghum and salinity: II. Gas exchange and chlorophyll fluorescence of sorghum under salt stress, Crop Science. 44 (2004) 806-811.

[43] M.A. Turan, N. Turkmen, N. Taban, Effect of $\mathrm{NaCl}$ on stomatal resistance and proline, chlorophyll, $\mathrm{Na}, \mathrm{Cl}$, and $\mathrm{K}$ concentrations of lentil plants, Journal of Agronomy. 6 (2007) 378-381.

[44] V.D. Tafouo et al., Growth, yield, water status, and ionic distribution response of three bambara groundnut landraces (Vigna subterranean (L.) Verdic.) grown under saline conditions, International Journal of Botany. 6(1) (2010) 53-58.

[45] E.B. Carpic1, N. Celık, G. Bayram, Effects of salt stress on germination of some maize (Zea mays L.) cultivars. African Journal of Biotechnology. 8(19) (2009) 4918-4922. 